\title{
福島県双葉郡の創造的教育復興を 支える学校と地域の連携·協働
}

中田スウラ

\section{東日本大震災後の10年と福島県の 子どもたち 一避難状況の推移}

東日本大震災（2011（平成23）年3月 11日、 以下「大震災」）の発生から 10 年が経つが、そ の特徴は、地震や津波だけでない原発震災を伴 う複合災害にある。その結果、発生した避難者 数は未だ 36,555 人になる（含避難先不明者 13 人)。内訳は、県外 29,307 人 1 、県内 7,235 人で ある ${ }^{2}$ (表 1$)$ 。県内避難者数の内訳は、双葉郡八 町村の合計が3,467人となり全体の $47.9 \%$ を占 める。また、18歳未満の子どもの避難状況をみ ると、県外避難者数が再び県内を逆転し、2020 年 4 月では県外が 5,690 人、県内が 802 人、合 計 6,492 人がまだ避難状況下にある ${ }^{3}$ 。全国平均 よりも高い水準で高齢化が進行し 20 歳未満の人 口率が $15.8 \%$ となる福島県の状況を勘案しても、 避難者に対する 18 歳未満避難者の率は $17.8 \%$ と 若干高く、子ども中心の避難傾向を再確認でき る4

表 1 福島県内避難者数内訳

(福島県災害対策本部 平成 23 年東北地方太平洋沖地震 による被害状況即報 2021 年 1 月 8 日） * : 双葉郡

\begin{tabular}{|c|c|c|c|c|c|c|}
\hline 田村市 & 南相馬市 & 川俣町 & 飯舘村 & * 大熊町 & *富岡町 & * 浪江町 \\
\hline 26 & 2,561 & 190 & 991 & 709 & 246 & 329 \\
\hline *楢葉町 & * 広野町 & * 葛尾村 & * 川内村 & * 双葉町 & 合計 & \\
\hline 774 & 347 & 99 & 441 & 522 & 7,235 & \\
\hline
\end{tabular}

\section{東日本大震災の影響と 双葉郡の小・中学校}

双葉郡に位置する八町村は浪江町、葛尾村、 双葉町、大熊町、富岡町、川内村、樽葉町、広 野町である。大震災前は、双葉郡には17小学校、 11 中学校、1 特別支援学校があった。震災後初 期の双葉郡各教育委員会の学校再開は、県外を 含む広範囲にわたる避難先で、あるいは可能な 場合には避難指示解除後に帰還して進められ、 懸命の努力が続いた5

今日では、各町村の教育委員会は可能な範囲 で州還し避難元での学校再開を一層進めている6。 2019年4月では、葛尾村、富岡町、川内村、楢 葉町、広野町の小・中学校は自町村内で学校を 再開している。また、広野町に福島県立ふたば 未来学園 (2015年高校・2019年中学校) が開校、 2018年4月には浪江町になみえ創成小学校・中 学校が開校した。現時点では浪江町と富岡町の 小・中学校では、前者が二本松市で、後者は三 春町で避難先の学校も同時運営しているが、双 葉郡全体では小学校 5 校、中学校 3 校、高校 5 校 が休校中である。双葉町と大熊町の小・中学校 では、前者がいわき市の、後者は会津若松市の 避難先での運営が続いている。

こうした展開の背景には、避難指示解除の進 展があり、帰還困難区域を大きく残す双葉町 · 
大熊町では避難先での学校運営が継続され、他 の町村では自町村で学校を再開している。この 現状の打開に向けて福島復興再生特別措置法が 改正された（2017年5月）。これにより、将来 にわたって居住を制限するとされてきた帰還困 難区域内に、避難指示を解除し居住を可能とす る「特定復興再生拠点区域」を定めることが可能 となった。その結果、各町村では、可能な範囲 で、帰還困難区域の再生に向けて、特定復興再 生拠点区域の設定及び同地区における環境整備 （除染やインフラ等の整備）に関する計画が作成 され、2017年から双葉町 · 大熊町 - 浪江町 - 富 岡町 - 葛尾村 · 飯舘村等での特定復興再生拠点
区域の認定が内閣総理大臣よりなされた。例え ば双葉町では、概ね 5 年をめどに、「まちなか再 生」「新市街地」「耕作再開モデル」「新産業創出」 「再生可能エネルギー活用・農業再生」等の視点 で各ゾーンが設定され復興の加速化が目指され ている。

こうした新たな段階で、双葉郡の小・中学校 の児童生徒数の推移を見直すとその実態は表2 の通りとなる。

単純に生徒数だけでは比較できないが、一部 帰還困難区域を残す町とそれ以外の町村とでは 増減傾向が異なる。避難先と避難元で再開校を 運営する富岡町は、全体として児童生徒の減少

\section{表2 福島県双葉郡町村立学校の概況}

(福島県双葉郡教育復興ビジョン推進協議会資料（H28.5.16 H H29.5.31）、福島県教育会館『教育関係者名簿』等から作成）

\begin{tabular}{|c|c|c|c|c|c|c|c|c|c|c|c|c|c|c|}
\hline & & H22年度 & 23 & 24 & 25 & 26 & 27 & 28 & 29 & 30 & 31 & $\mathrm{R} 2$ & R2/H22 & *平成31年は4月末日まで, 5 月1日からは令和元年 \\
\hline 浪江町 & 小学校 & 1162 & 0 & 29 & 17 & 22 & 14 & 11 & 5 & 11 & 16 & 22 & $1.9 \%$ & \multirow{3}{*}{$\begin{array}{l}\text { 【二本松市】 H23.8 二本松市の廃校で小・中学校各 } 1 \text { 校、H26.4に小 } 1 \\
\text { 校を再開。児童生徒数は大幅減。福島大学や地域連携でふるさと浪江との } \\
\text { 結びつきをを重視した教育活動を展開。小学校: } 5 \text { 校休校、津島小・創成小 } \\
\text { (H30 開校)。中学校 : } 3 \text { 校休校、創成中 (H30 開校)のみ。 }\end{array}$} \\
\hline 解除済 & 中学校 & 611 & 0 & 49 & 43 & 25 & 20 & 17 & 9 & 6 & 2 & 5 & $0.8 \%$ & \\
\hline 一部帰還困難区域 & 小計 & 1773 & 0 & 78 & 60 & 47 & 34 & 28 & 14 & 17 & 18 & 27 & $1.5 \%$ & \\
\hline 葛尾村 & 小学校 & 68 & 0 & 0 & 14 & 12 & 10 & 9 & 9 & 7 & 7 & 8 & $11.8 \%$ & \multirow{3}{*}{ 【三春町】H25.4三春町の廃校で学校再開。H30.4葛尾村で学校再開。 } \\
\hline 解除済 & 中学校 & 33 & 0 & 0 & 6 & 8 & 11 & 11 & 13 & 11 & 7 & 5 & $15.2 \%$ & \\
\hline 一部帰還困難区域 & 小計 & 101 & 0 & 0 & 20 & 20 & 21 & 20 & 22 & 18 & 14 & 13 & $12.9 \%$ & \\
\hline 双葉町 & 小学校 & 343 & 0 & 0 & 0 & 4 & 6 & 19 & 26 & 31 & 35 & 30 & $8.7 \%$ & \multirow{3}{*}{$\begin{array}{l}\text { 【いわき市】 H25.6行政機能を埼玉県加須市からいわき市に移転。H26.4 } \\
\text { いわき市錦町作鞍で学校再開。H26.8いわ市錦町御宝殿の仮設校舎に } \\
\text { 移転、継続中。 }\end{array}$} \\
\hline 解除済 & 中学校 & 208 & 0 & 0 & 0 & 7 & 9 & 9 & 11 & 12 & 12 & 12 & $5.8 \%$ & \\
\hline 一部帰還困難区域 & 小計 & 551 & 0 & 0 & 0 & 11 & 15 & 28 & 37 & 43 & 47 & 42 & $7.6 \%$ & \\
\hline 大熊町 & 小学校 & 756 & 351 & 265 & 178 & 128 & 67 & 38 & 25 & 19 & 12 & 9 & $1.2 \%$ & \multirow{3}{*}{$\begin{array}{l}\text { 【会津若松市】H23.4会津若松市の廃校で学校再開。学校を中心にコミュ } \\
\text { 二テイ維持を図った効果で震災後初期には } 50 \% \text { が就学。福島大、会津大 } \\
\text { 連携で充実した教育活動を展開。H25.4中学校を会津大短期大学部内の } \\
\text { 仮設校舎に移転。保護者の仕事事情でいわき市へ子どもの転出か続く。 }\end{array}$} \\
\hline 解除済 & 中学校 & 371 & 214 & 159 & 119 & 68 & 43 & 25 & 20 & 13 & 3 & 3 & $0.8 \%$ & \\
\hline 一部帰還困難区域 & 小計 & 1127 & 565 & 423 & 297 & 196 & 110 & 63 & 45 & 32 & 15 & 12 & $1.1 \%$ & \\
\hline 富岡町 & 小学校 & 937 & 0 & 32 & 31 & 23 & 16 & 15 & 11 & 25 & 25 & 35 & $3.7 \%$ & \multirow{3}{*}{$\begin{array}{l}\text { 【三春町】H23.9三春町にある工場跡地で学校再開。H30.4に避難元町 } \\
\text { 内での学校再開。三春校は2021 (R3) 年度まで継続予定。 }\end{array}$} \\
\hline 解除済 & 中学校 & 550 & 0 & 39 & 31 & 26 & 23 & 18 & 19 & 14 & 20 & 14 & $2.5 \%$ & \\
\hline 一部帰還困難区域 & 小計 & 1487 & 0 & 71 & 62 & 49 & 39 & 33 & 30 & 39 & 45 & 49 & $3.3 \%$ & \\
\hline 川内村 & 小学校 & 112 & 0 & 16 & 24 & 26 & 35 & 35 & 45 & 38 & 39 & 44 & $39.3 \%$ & \multirow{3}{*}{$\begin{array}{l}\text { 【帰還済】H23.4郡山市内の学校を間借りして学校再開。H24.4緊急時 } \\
\text { 避難指示準備区域解除に伴い村内の自校に帰還。R3 年度から、小学校と } \\
\text { 中学校とを改修した新校舎 } 1 \text { 校に統合し、小中一貫教育の義務教育学校を } \\
\text { 運営する。 }\end{array}$} \\
\hline 解除済 & 中学校 & 54 & 0 & 14 & 16 & 17 & 13 & 14 & 17 & 26 & 26 & 27 & $50.0 \%$ & \\
\hline & 小 計 & 166 & 0 & 30 & 40 & 43 & 48 & 49 & 62 & 64 & 65 & 71 & $42.8 \%$ & \\
\hline 楢葉町 & 小学校 & 432 & 0 & 63 & 24 & 87 & 81 & 72 & 62 & 68 & 82 & 98 & $22.7 \%$ & \multirow{3}{*}{ 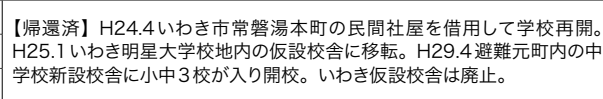 } \\
\hline 解除済 & 中学校 & 254 & 0 & 40 & 63 & 73 & 64 & 56 & 43 & 33 & 27 & 38 & $15.0 \%$ & \\
\hline & 小計 & 686 & 0 & 103 & 87 & 160 & 145 & 128 & 105 & 101 & 109 & 136 & $19.8 \%$ & \\
\hline 広野町 & 小学校 & 311 & 0 & 57 & 69 & 91 & 110 & 142 & 143 & 151 & 160 & 154 & $49.5 \%$ & \multirow{3}{*}{ 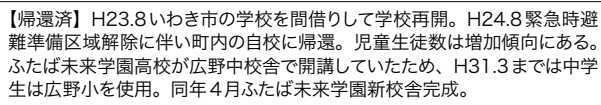 } \\
\hline 解除済 & 中学校 & 230 & 0 & 22 & 42 & 50 & 66 & 69 & 83 & 66 & 76 & 68 & $29.6 \%$ & \\
\hline & 小 計 & 541 & 0 & 79 & 111 & 141 & 176 & 211 & 226 & 217 & 236 & 222 & $41.0 \%$ & \\
\hline 双葉郡 計 & 小学校 & 4121 & 351 & 462 & 357 & 393 & 339 & 341 & 326 & 350 & 376 & 400 & $9.7 \%$ & \multirow{3}{*}{ 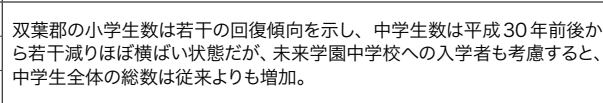 } \\
\hline & 中学校 & 2311 & 214 & 323 & 320 & 274 & 249 & 219 & 215 & 181 & 173 & 172 & $7.4 \%$ & \\
\hline & 合 計 & 6432 & 565 & 784 & 677 & 667 & 588 & 560 & 541 & 531 & 549 & 572 & $8.9 \%$ & \\
\hline & & $100.0 \%$ & $8.8 \%$ & $12.2 \%$ & $10.5 \%$ & $10.4 \%$ & $9.1 \%$ & $8.7 \%$ & $8.4 \%$ & $8.3 \%$ & $8.5 \%$ & $8.9 \%$ & - & \\
\hline ふたば未来学園中学校 & - & - & - & - & - & - & - & - & - & - & 81 & 132 & - & $\begin{array}{l}\text { 未来学園中学校への入学者も含めた双葉郡全体の中学生の総数は、H31 } \\
\text { 年度が630人 (9.8\%)、R2 年度が704人 (10.9\%)。 }\end{array}$ \\
\hline
\end{tabular}


傾向を示すが、少ないながらも現時点ではそれ を維持している。川内村・楢葉町・広野町では 減少から転じ、若干の回復傾向を見せている。

避難元での学校再開以上の展開を見せるのが 浪江町である。避難先の再開校を集約させなが ら避難元の町内に新たに「なみえ創成小・中学 校」を改修した浪江東中学校校舎に開設した。 2020 年度では、小学校は避難先の二本松市での 再開校となる津島小学校（6年生 1 人在籍）と新 設された「なみえ創成小学校」とが開校されてお り、それ以外は休校である。中学校は「なみえ 創成中学校」のみの開校である。浪江町の新設 校への集約は避難先での在籍児童生徒の卒業を 待って完了する。大震災前に6小学校と3中学 校を有し学校数が多かった浪江町がこの方針を 見いだすのに 10 年を要しているが、その背景に は未だ多くの区域外就学者の存在がある。2016 （平成 28）年 10月31日時点での区域外就学の児 童生徒数は、県内約 830 人、県外約 470 人で合 計約 1,300 人となり、それに比して浪江町立の 小・中学校の在籍児童生徒数は 10 月の時点で 9 人である7 。浪江町に区域外就学を含め住民票を おく児童生徒の存在は重く、小・中学校の休校・ 開校に関しては慎重な検討がなされ、浪江小． 中学校を初めとする各学校をいずれかの学校に 再編統合するのではなく、各学校の歴史・伝統 を引き継ぐ「なみえ創成小・中学校」を新しく開 設することが決定された。この決定は、改めて 地元での学校開校を、地域の人材育成と地域づ くりとを両立させるための本格的な契機とする ことを意図したものである。
避難先での学校再開を継続する双葉町・大熊 町や、避難元での再開校と避難先の再開校を持 つ富岡町の今後の動向も浪江町と同様に注目さ れる。また、川内村は帰村し2012年度に学校再 開したが、川内小学校と川内中学校を集約し、 認定こども園や村営学習塾、放課後子ども教室、 地域のコミュニティスペースを加え複合施設化 した義務教育学校を 2021（令和3）年度から開校 し小中一貫教育に着手する。

\section{双葉郡教育復興の挑戦「ふるさと 創造学」一学校と地域の連携・協働}

双葉郡の教育復興は、双葉郡八町村の教育長 会が中心となり策定された「双葉郡教育復興ビ ジョン」 ${ }^{8}$ および「福島県双葉郡教育復興ビジョ ン推進計画書」 ${ }^{9} に$ 基づき推進されている。その 学習課程上の特徴は、アクティブ・ラーニング、 ICT教育、教育のグローバル化、そしてそれら を総合的に展開する「ふるさと創造学」等にみら れる。「ふるさと創造学」は各学校の個性を活か しつつ地域を題材にその課題を共同的に把握し その解決を求めて協働的に進められる探究的学 習の展開である。それは一つの「地域学習」 ${ }^{10}$ と も言えるが、八町村の学校が地域を題材にとも に取り組む探究的な学習の総称とされる ${ }^{11}$ 。2014 年度から郡内の小・中学校で、翌年度から福島 県立ふたば未来学園高等学校でも開始され、同 中学校にも継承されている。

双葉郡教育復興の目的は、「『ふるさと創造学』 では、震災や原発事故を通じ子どもたちが得た 
経験を生きる力に変え、ふるさとへの誇りと自 ら未来を創造する思いを育む。子どもたちが日 常生活や地域社会に目を向け、課題発見と解決 のために考え学び行動する探究的な学習を通し て、主体性・協働性・創造性を伸ばすことをね らいとする」 ${ }^{12}$ と示された。

即ち、「ふるさと創造学」に象徵される双葉 郡の教育復興は、地域復興とその人材育成を同 時に進め、学校と地域の連携・協働を図ること を意図している。富岡町では避難元での学校再 開に関わり「学校がコミュニティの拠点」とな り「生きる力を育む学校教育」を進め、同時にそ れを支えるため「人がつながる多世代教育」「文 化をつむぐ多世代教育」の推進をテーマに掲げ、 地域住民の参加と協働による「多世代教育」に一 つの活路を見いだしている ${ }^{13}$ 。そうした方向性を 一歩進め、浪江町や川内村では新設校の開校に ともないコミュニティ・スクールを導入した ${ }^{14}$ 。 それにより川内村の開設予定の義務教育学校そ して浪江町の新設校は、地域住民や保護者など の参画による学校運営を促進させようとしてい る。いずれも、原発震災の影響を受けた児童生 徒数の減少を、効果的な少人数教育による改善 やICT教育を活用したグローバル化・学校間連 携等で補う他、従来以上に学校と地域の一体化 を進める「地域とともにある学校」 ${ }^{15}$ の創造に挑 戦するといった教育推進の展開である。

今後の 2021 年度からの 5 年間は「第 2 期復興 • 創成期間」とされ、「第 1 期復興・創生期間」の 理念を継承し、その目標の実現に向け取組をさ らに前に進めるべき時期とされた。双葉郡の教
育復興もこの 10 年間の蓄積を活かした更なる推 進が期待されるが、学校と地域とのパートナー シップによる連携・協働の内実を地域状況に即 し具体的に構築することが今後一層求められて いる。

注

1 http://www.pref.fukushima.lg.jp/site/portal/ps-kengaihinansyasu.html, ふくしま復興ステーション, 2020年12月8日。

2 福島県災害対策本部「平成 23 年東北地方太平洋沖地震によ る被害状況即報 (第1772 報)」令和3 年1月8日。

3 福島県こども・青少年政策課「東日本大震災に係る18歳未満 の子どもの避難者数調べ」2020年 4 月1日。

4 福島県「震災以降の人口減少—少子. 高齢化の状況」 2015 年2月26日。福島県統計課「福島県の推計人口」2021 年2月1日。

5 福島県双葉郡教育復興ビジョン推進協議会広報誌〈ふたばの 教育vol. 3〉、2015年3月。

6 福島県双葉郡教育復興ビジョン推進協議会「2019年双葉 郡 8 町村の学校のいま」https://futaba-educ.net/district/ school

7 浪江町町立小・中学校に係る検討委員会「帰還後の浪江町で の新たなまちづくりの中で、状況変化に対応しつつ町立小・中 学校の在り方を適切なものにするための基本的方策について一 一検討経過とその内容」2017年2月。

8 福島県双葉郡教育復興に関する協議会「福島県双葉郡教育 復興ビジョン」、平成 25 年 7 月 31 日。

9 福島県双葉郡教育復興ビジョン推進協議会「福島県双葉郡 教育復興ビジョン推進計画書」、平成28年3月29日。

10 宮城農民大学編『地域学習の灯をともして』ひかり書房、昭和 54 年。佐藤一子編『地域学習の創造』平成 27 年、東京大学 出版。

11 福島県双葉郡教育復興ビジョン推進協議会〈ふたばの教育 vol. 7$\rangle$ 平成 29 年 3 月、p. 2 。

12 福島県双葉郡教育復興ビジョン推進協議会「福島県双葉郡 教育復興ビジョン推進計画書」、平成28年3月29日、p. 3。

13 富岡町教育委員会「福島県双葉郡富岡町『学校再開に向け て』」平成29年11月1日。

14 浪江町立学校校舎等検討委員会「浪江町立学校の校舎等の 今後の在り方の適正化を図るための基本的方策について（答 申)」令和元年 11 月 21 日。川内村教育委員会「川内村小中 一貫教育・学校施設複合化施設整備基本構想・基本計画報 告書一一小中一貫教育・学校施設の複合化に関する先導的 検討プロセス構築支援事業」平成 30 年 3 月。

15 中央教育審議会答申「新しい時代の教育や地方創生の実現 に向けた学校と地域の連携・協働の在り方と今後の推進方策 について」平成 27 年 12 月 21 日。 